\title{
The Effect of Leadership and Organizational Culture on Employee Performance
}

\author{
Atikah Sofa Tianingrum ${ }^{1}$ \\ ${ }^{1}$ Universitas Sultan Ageng Tirtayasa \\ ${ }^{1}$ Jl. Raya Palka No.Km 3, Panancangan, Kec. Cipocok Jaya, Serang, Banten 42124 \\ e-mail: atikahtianingrum@gmail.com ${ }^{1}$
}

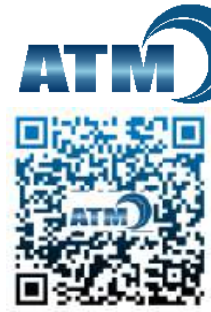

Author Notification

25 October 202

Final Revised

26 November 2021

Published

1 July 2022

To cite this document :

Tianingrum, S.A., (2022). The Effect of Leadership and Organizational Culture on Employee Performance. Aptisi Transactions on Management (ATM), 6(2), 158-166.

DOI :

https://doi.org/10.33050/atm.v6i2.1746

\begin{abstract}
Currently, many construction companies offer construction services for Pile Foundation work and Bored Pile or Struss Pile for Buildings, Bridges, BTS Towers, Residential Houses, Shophouses, Hotels and the like using the Bored Pile or Strauss Pile method. The problem that exists is because of the influence of employee performance on construction where there are still some employees who are not satisfied with the leadership. This study aims to determine the effect of influence on employee performance and to see the influence of Organizational Culture on employee performance. This study tested three hypotheses with data sources originating from respondents from PT. Queen of the Great Foundation. Information, primary and secondary data in this study were only obtained from PT. Queen of the Great Foundation. The population and sample of this study were all employees of PT. The Great Foundation Queen of various divisions that opened 90 people. This study uses a quantitative approach method. The data collection technique used primary data in the form of a questionnaire. The data analysis technique of this research used the Structural Equation Modeling-Partial Least Square (SEMPLS) method. This study shows that 1) Leadership has a positive and significant effect on Employee Performance, 2) Leadership has a positive and significant influence on Organizational Culture, 3) Organizational culture has a positive and significant influence on employee performance.
\end{abstract}

\section{Keywords: Leadership, Organizational Culture, Employee Performance}

\section{Introduction}

Along with the times, development in Indonesia has spread, concentrated in big cities, and has penetrated the regions all over the country. Many large buildings such as buildings, bridges, towers, and other buildings were erected during the construction. To withstand the heavy building load, of course, a solid foundation is needed. If the soil conditions on the surface cannot withstand the building, then the building load must be transferred to the hard soil layer below it. For this reason, deep foundation construction is often used in the form of piles or bored piles.

Pile foundations are often used on land that is still wide and empty, where the vibrations generated during piling activities do not interfere with the surrounding environment. can damage surrounding buildings. In this case, the use of a bored pile foundation is the right foundation choice in large projects where the means of transportation support, in the manufacture of bored piles, heavy equipment in the form of cranes are often used. However, for small projects, especially if the means of transportation are not supportive, cranes often have difficulty because it requires significant funding to mobilize so that the project costs become uneconomical.

To overcome the problems mentioned above, PT. Ratu Foundation Agung is a contractor company engaged in Construction Services, especially Pile Foundation work and Bored Pile or Struss Pile for Buildings, Bridges, BTS Towers, Residential Houses, Shophouses, 
Hotels and the like with the Bored Pile or Strauss Pile method. This company uses Jacking Pile equipment and mini crane drills, which are compact and easy to mobilize and operate. This equipment has the following advantages: Easy to operate on rugged terrain such as: Over rivers and seas: Hilly or mountainous areas. The Swamp area is Compact and practical so that it is easy and cheap to mobilize. Does not cause vibration. This is very important, especially for foundation construction in urban areas where the buildings are pretty dense and do not allow piles.

This study focuses on the performance of existing employees at PT Ratu Pondasi Agung. Performance is an achievement displayed by an employee in completing his work with a certain level of motivation and ability according to his role in the company [1]. Performance has the most crucial role. If performance decreases, it will gradually threaten the company and result in the company going bankrupt. In this case, employees are always required to produce a better performance to achieve company goals effectively and efficiently. There are always problems that arise within the company where sometimes the performance results produced by employees are not good enough, one of which happened at PT. Ratu Foundation Agung, wherein the business phenomenon data shows the low performance of employees.

One of the critical elements of success for companies is the ability of managers to motivate employees to reach their potential and accept change [2]. The success of an organization will be determined by the ability of the leader to organize the resources they have, including human resources. Business conditions are changing very dynamically, the role of leaders is vital for the success of an organization. Leadership is the ability to influence people to try voluntarily to achieve goals [3]. Leadership is about dealing with change [4]. Leadership style is a management tool used to improve positive relationships with employees, improve organizational climate, and improve performance [5]. The leader of an organization has the authority to determine how the organization will be run and has a role in influencing the culture within the organization [6].

Furthermore, a strong culture of an organization will help increase the level of performance [7]. Leadership plays a vital role in creating an atmosphere and culture in an organization [8]. Kotter \& Heskett [6] say that a strong culture can produce effects that significantly affect individuals and performance. Even in a competitive environment, the influence can be more significant than other factors, such as organizational structure, financial analysis, and others. Some of these studies show a link between leadership, culture, and employee performance. Based on the results of previous studies and the role of organizational culture in improving employee performance and the phenomena that exist in PT. Ratu Foundation Agung, it is interesting to study the Influence of Leadership and Organizational Culture on Employee Performance.

\section{Review Library}

\subsection{Theoretical basis \\ Leadership}

Sutrisno,[9] "Leadership is a process of directing and influencing activities related to group members' tasks." Fahmi [10], "Leadership is a science that studies comprehensively about how to direct, influence, and supervise others to do tasks by the planned orders." Fahmi [10], "Leadership is a science that studies comprehensively about how to direct, influence, and supervise others to do tasks following the planned orders." Meanwhile,Terry in Irham Fahmi [11], "Leadership is the activity of influencing people to strive willingly for mutual objectives." (Leadership is an activity that influences people to try to achieve a common goal willingly). Indicators of Leadership R. Terry in Fahmi [12], there are several indicators in understanding leadership, namely:

1. Emotional Stability

Emotional stability is an individual's reaction, both emotional and physical, predictable and not surprising. A leader should not be prejudiced against his subordinates, and he should not be quick to anger and believe in himself must be big enough.

2. Human Relations

Know human relations. The interaction process carried out by humans is persuasive communication involving psychology, feelings, and human thoughts.

3. Personal Motivation 
The desire to be a leader must be great, have a high commitment, be responsible, wise, rely on well on upon, and motivate oneself.

4. Communication Ability

Have communication skills to direct employees to continue progress and develop and communicate thoughts, ideas, feelings, and desires.

\section{Employee performance}

Employee performance is a rating system used in many organizations to evaluate the ability and efficiency of employees. Chen in Ahmad et all [13], employee performance relates to employees who complete their tasks and goals up to the standards defined by the organization, and their work is assessed based on performance against the set performance standards. Every employee is required to make a positive contribution through good performance, considering that organizational performance depends on the performance of its employees. Dessler in Bryan [14], employee performance is work performance, namely the comparison between work results seen in real terms with work standards that the organization has set. Then defines performance, namely a result achieved by employees in their work according to specific criteria that apply to a job [15]. Employee Performance Indicators Bernadine in Bryan [16], employee performance indicators can be measured:

1. Quality, the degree to which the results of the activities carried out are near perfect, in the sense of adjusting to some ideal way of performing the activity or meeting the expected goals of the activity.

2. Quantity, The amount produced in terms of the number of units, the number of activity cycles completed.

3. Timeliness, The level of an activity completed at the desired initial time, from the point of view of coordinating with the output results and maximizing the time available for other activities.

4. Effectiveness, the level of use of the organization's human resources, is maximized to increase profits or reduce losses from each unit in the use of resources.

5. Independence, the degree to which an employee can perform his work function without asking for guidance from the supervisor or asking the supervisor to intervene to avoid adverse results.

\subsection{Hypothesis Development}

\section{Employee leadership and performance}

Leadership is a process of influencing a group of people to achieve organizational goals [17]. Another opinion states that leadership is influencing people to get the desired results [18]. Leadership is an effort to influence individual and group efforts to achieve organizational goals [19]. Various understandings of leadership, in principle, are the ability of a person to influence and direct a person or group of people so that organizational goals are achieved. The research results by Syafii et al. [20] states that three variables affect employee performance, namely leadership style, organizational culture, and work motivation. Basit et al. [21] found that the democratic leadership style has a significant positive impact on employee performance, while the autocratic leadership style has a negative effect. It was further explained that when a democratic approach is applied, employee performance will increase. Widodo [22], in his research, explains that leadership affects performance because leadership will encourage subordinates to work better.

$\mathrm{H} 1$ : Leadership has a positive and significant effect on employee performance.

\section{Leadership and Organizational Culture}

Al-Ali et al. [23] stated that change leadership has a positive and significant influence on the dimensions of organizational culture in the public sector. Furthermore, Sihombing et al. [24] stated that servant leadership affects rewards and organizational culture. Paschal \& Nizam's research [25] explains that organizational culture significantly impacts employee performance. This study explains that culture depends on leadership and how leaders build and maintain a culture.

H2: Leadership has a positive effect on Organizational Culture

\section{Organizational Culture and employee performance}

Organizational culture is based on a set of values, assumptions, beliefs, and behaviors and how they collectively affect change, employees, and performance [26]. Previous researchers 
have researched the relationship between performance culture and the results that organizational culture significantly affects performance. Research findings indicate that a strong culture of an organization will help increase performance [27]. Weerasinghe's research [28] concludes that organizational culture will empower teamwork and increase morale in their work to achieve good performance results. In line with these findings, Sihombing et al. [24] also succeeded in testing a significant influence between organizational culture and employee performance. In the organizational context, Ahmad [29] stated that the dimensions of organizational culture have a significant positive relationship with performance management practices. It is further explained that performance management as a fundamental human resource management practice supports the view that employees and managers benefit from understanding organizational culture as a contextual factor.

H3: Organizational Culture has a positive and significant effect on employee performance.

\section{3 conceptual framework}

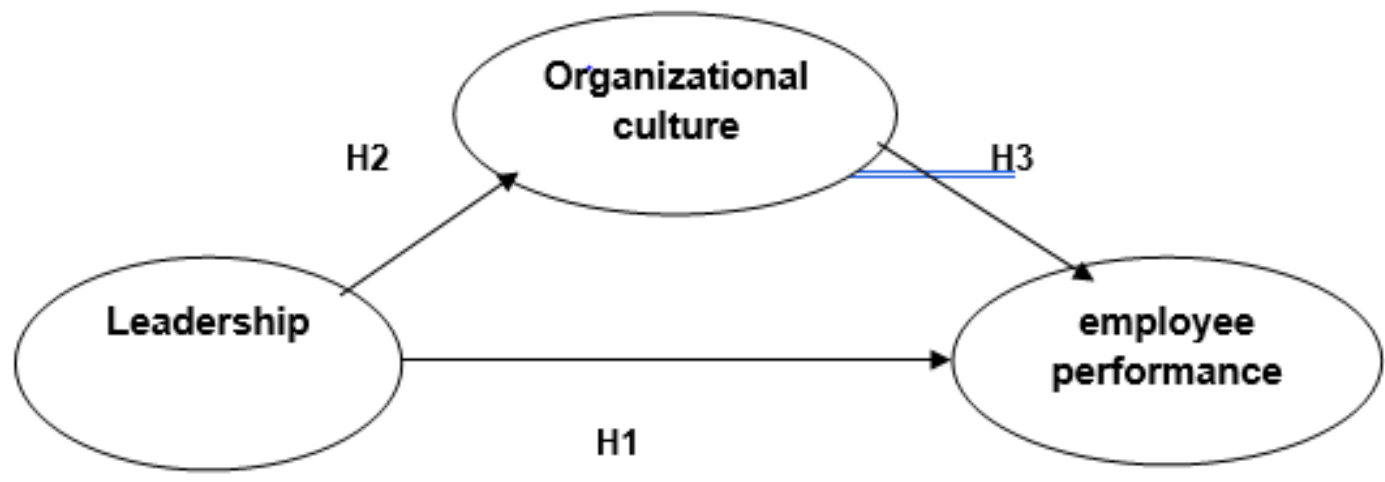

Figure 1 Conceptual Framework Model

\section{Research Method}

This type of research is quantitative research. The number of samples used is 90 samples. The analytical tool used is Partial Least Square (PLS), which is SEM based on variance. The data collection method used is by distributing personal questionnaires or questionnaires. The measurement uses a scale with a value range of 1 to 10 . Number 1 indicates the answer strongly disagrees, while the number 10 indicates the answer strongly agrees

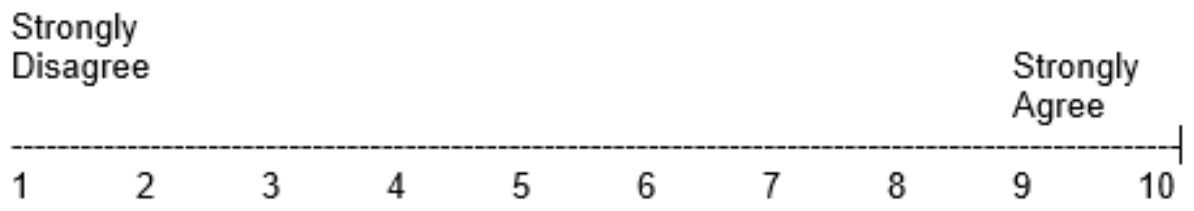

\section{Result and Discussion}

Source: Ferdinand, [30]

\subsection{Results}

\section{Testing Outer Model}

In testing, the outer model aims to see the validity and reliability of a model. The analysis of this test will be seen from the influence of Factor Loading, Average Variance Extracted (AVE), and Discriminant Validity, as well as composite reliability.

\section{a) Construct Validity Test}

Factor loading is the initial stage in testing the validity of a model, the condition for factor loading is that it must be $>0.6$ so that the indicator is said to be valid. If it is not valid, it must be removed from the model [31]. To find out the outer analysis of this research model, it can be seen in Figure 2 below: 


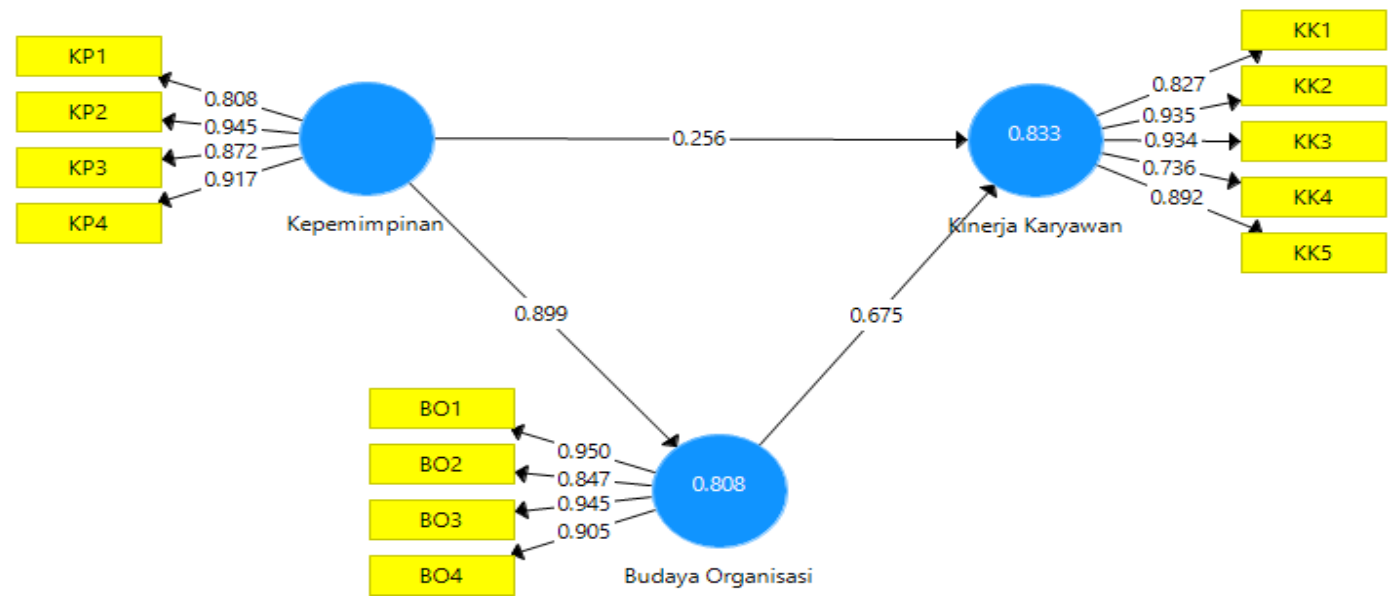

Figure 2 Outer model algorithm results

Ghozali [32], an indicator is said to meet convergent validity if it has a loading factor value of 0.5 to 0.7 . In this study, the critical limit of the loading factor used is 0.7 . Based on Figure 2, it can be seen that the loading factor value of all indicators has a value above 0.7 . Thus, these results indicate that the indicator meets good convergent validity.

b) Construct Reliability Test

\begin{tabular}{|l|r|r|r|r|} 
& Cronbach's Alpha & rho_A & Composite Reliability & Average Variance Extracted (AVE) \\
\hline Budaya Organisasi & 0.933 & 0.938 & 0.952 & 0.834 \\
\hline Kepemimpinan & 0.909 & 0.915 & 0.937 & 0.787 \\
\hline Kinerja Karyawan & 0.916 & 0.928 & 0.938 & 0.754 \\
\hline
\end{tabular}

Table 1 (Results of Construct Reliability Testing based on Convergent Validity)

From the table above, the Cronbach's Alpha value of each variable has a value $>$ 0.6 , so it can be concluded that the indicator is consistent in measuring the construct. The AVE value is used to show how much variance the indicator contains in the construct. As a result, it can be seen that the AVE value of each variable has a value > 0.5 . The Composite Reliability value has a value $>0.7$, so all variables are declared reliable.

Inner Model Test

a) Coefficient of Determination

\begin{tabular}{lrr} 
& R Square & R Square Adjus... \\
\hline Budaya Organisasi & 0.808 & 0.806 \\
\hline Kinerja Karyawan & 0.833 & 0.829 \\
\hline Table 2 (Coefficient of Determination R2) &
\end{tabular}

Based on the study results, it is known that the $\mathrm{R}$ Square of Organizational Culture is 0.833. Employee performance in the structural model is influenced by Leadership and 
Organizational Culture. Therefore, these results indicate that the two variables, namely Leadership and Organizational Culture, can explain the Employee Performance variable by $83.3 \%(0.833 \times 100 \%)$. Meanwhile, the remaining $16.7 \%$ is explained by other variables not examined. The picture also shows the R Square value of Organizational Culture of 0.808 . Organizational Culture in the structural model is influenced by Leadership. Thus these results indicate that performance leadership can explain the organizational culture

\section{b) Hypothesis test}

Testing the direct influence hypothesis is carried out to determine the structural relationship between latent variables on the path coefficient between variables by comparing the P-value with alpha (0.005) or t-statistics of $(>1.96)$. The magnitude of the Pvalue and also the t-statistics can be seen in table 3 .

\begin{tabular}{|lrrrrrr|}
\hline & Original Sample (0) & Sample Mean (M) & Standard Devia... & T Statistics (O/STDEV) & P Values \\
\hline Budaya Organisasi -> Kinerja Karyawan & 0.675 & 0.671 & 0.121 & 5.590 & 0.000 \\
\hline Kepemimpinan $>$ Budaya Organisasi & 0.899 & 0.900 & 0.017 & 53.314 & 0.000 \\
\hline Kepemimpinan $>$ Kinerja Karyawan & 0.256 & 0.262 & 0.126 & 2.042 & 0.042 \\
\hline
\end{tabular}

Table 3 (Hypothesis test results)

\subsection{Discussion}

\section{Hypothesis Testing 1}

H1: Leadership has a positive and significant influence on employee performance The influence of leadership on employee performance is indicated by the original sample value of 0.256 with a positive sign, which means that leadership positively affects employee performance. This result indicates that the better the leadership, the higher the employee's performance. This means that leadership has a positive and significant effect on employee performance.

\section{Hypothesis Testing 2}

H2: Leadership has a positive and significant influence on Organizational Culture

The influence of Leadership on organizational culture is indicated by the original sample value of 0.899 with a positive sign, which means that Leadership has a positive effect on organizational culture. These results indicate that the better the Leadership, the better the Organizational Culture. Based on table 3 , the P-Value value is $0.000<0.05$ or with a T statistic of $53,314>1.96$ then $\mathrm{H} 1$ is accepted. This means that Leadership has a positive and significant effect on Organizational Culture.

\section{Hypothesis Testing 3 \\ H3: Organizational Culture has a positive and significant influence on employee performance}

The influence of organizational culture on employee performance is indicated by the original sample value of 0.675 with a positive sign, which means that organizational culture has a positive effect on employee performance. These results indicate that the better the organizational culture, the higher the employee's performance. Based on table 3 , the PValue value is $0.000<0.05$, or with a T statistic of $5.590>1.96$, then $\mathrm{H} 1$ is accepted. This means that organizational culture has a positive and significant effect on employee performance. 


\section{Conclusion}

The hypothesis testing by statistical means on the effect of each independent variable on the dependent variable produces the following conclusions:

1. Leadership has a positive and significant influence on employee performance. From these conclusions, based on the T Statistics value of 2,042 > 1.96 and the P-Value of $0.042<0.05$, the leadership is getting better, the employee's performance will increase.

2. Leadership has a positive and significant influence on Organizational Culture. From these conclusions, based on the T Statistics value of $53,314<1.96$ and the P-Value of $0.000>$ 0.05 , it means that the better the leadership, the better the organizational culture.

3. Organizational culture has a positive and significant influence on employee performance. From these conclusions based on the value of T Statistics. of $5.590>1.96$ or P-value of $0.000<0.05$. This means that the better the organizational culture, the higher the employee's performance.

\section{Suggestion}

Suggestions for management so that they can continue to improve employee performance by doing good relations with leaders and vice versa Leaders must also have good relations with their employees so that a company will run well if the creation of good leaders and implementing a work culture in the Company is implemented. Employee performance will be good if the Leaders and work culture carried out in the Company are carried out correctly and structured. 


\section{References}

[1] H. Aima, M. M. Rizki Adam, and C. M. A. Hapzi Ali, "Model of Employee Performance: Competence Analysis and Motivation (Case Study atPT. Bank Bukopin, Tbk Center)," Leadership, vol. 5, no. 5, 2017.

[2] E. Cameron and M. Green, Making sense of change management: A complete guide to the models, tools and techniques of organizational change. Kogan Page Publishers, 2019.

[3] R. Gyanchandani, "The effect of transformational leadership style on team performance in IT sector," IUP J. Soft Ski., vol. 11, no. 3, pp. 29-44, 2017.

[4] C. Dumas and R. H. Beinecke, "Change leadership in the 21st century," J. Organ. Chang. Manag., 2018.

[5] B. E. Maamari and J. F. Majdalani, "Emotional intelligence, leadership style and organizational climate," Int. J. Organ. Anal., 2017.

[6] D. D. Warrick, "What leaders need to know about organizational culture," Bus. Horiz., vol. 60, no. 3, pp. 395-404, 2017.

[7] S. Einarsen, A. Skogstad, E. Rørvik, Å. B. Lande, and M. B. Nielsen, "Climate for conflict management, exposure to workplace bullying and work engagement: a moderated mediation analysis," Int. J. Hum. Resour. Manag., vol. 29, no. 3, pp. 549-570, 2018.

[8] T. Anning-Dorson, R. K. Odoom, G. Acheampong, and E. Tweneboah-Koduah, "Innovation and organizational development: the role of organizational leadership," African J. Econ. Manag. Stud., 2017.

[9] A. Khalik, A. A. Musyaffa, and H. Ali, "The Effect of Leadership Style on Productivity through Teacher Motivation in Madrasah Aliyah Negeri 1 Jambi City," Linguist. Antverp., vol. 3, 2021.

[10] S. Harun, F. Farchan, G. Gunawan, and D. A. Rahman, "The Influence of Personality, Empowerment, and Leadership on Job Satisfaction of Employee in Indramayu Education Departement," in International Conference on Agriculture, Social Sciences, Education, Technology and Health (ICASSETH 2019), 2020, pp. 17-23.

[11] A. Novialumi, "The Effect of Servant Leadership on the Work Productivity of PT. Fastrata Buana Bekasi," Int. J. Educ. Inf. Technol. Others, vol. 4, no. 1, pp. 143-147, 2021.

[12] M. Ani Marlia, R. Fahmy, H. Lukito, R. Prima Lita, and R. Rahim, "Visionary leadership role: Building a ghost town civilization," Int. J. Manag., vol. 11, no. 1, pp. 31-55, 2020.

[13] Y. Chen, R. Ning, T. Yang, S. Feng, and C. Yang, "Is transformational leadership always good for employee task performance? Examining curvilinear and moderated relationships," Front. Bus. Res. China, vol. 12, no. 1, pp. 1-28, 2018.

[14] N. K. Wardhani, "Influence of competence, transformational leadership, social capital and performance on employee careers," IJHCM (International J. Hum. Cap. Manag., vol. 1, no. 02, pp. 81-94, 2017.

[15] K. I. R. Sudiardhita, S. Mukhtar, B. Hartono, T. Sariwulan, and S. I. Nikensari, "The effect of compensation, motivation of employee and work satisfaction to employee performance Pt. Bank Xyz (Persero) Tbk," Acad. Strateg. Manag. J., vol. 17, no. 4, pp. $1-14,2018$.

[16] S. Hong, "A behavioral model of public organizations: Bounded rationality, performance feedback, and negativity bias," J. Public Adm. Res. Theory, vol. 29, no. 1, pp. 1-17, 2019.

[17] R. Tannenbaum and W. H. Schmidt, How to choose a leadership pattern. Routledge, 2017.

[18] L. V Casaló, C. Flavián, and S. Ibáñez-Sánchez, "Influencers on Instagram: Antecedents and consequences of opinion leadership," J. Bus. Res., vol. 117, pp. 510-519, 2020.

[19] B. Shamir and J. M. Howell, "Organizational and contextual influences on the emergence and effectiveness of charismatic leadership," in Leadership now: Reflections on the legacy of Boas Shamir, Emerald Publishing Limited, 2018.

[20] G. N. S. Putra and I. G. A. M. Dewi, "Effect of transformational leadership and organizational culture on employee performance mediated by job motivation," Int. Res. J. Manag. IT Soc. Sci., vol. 6, no. 6, pp. 118-127, 2019.

[21] M. T. I. Jony, M. J. Alam, M. R. Amin, and M. Jahangir, "The Impact of Autocratic, Democratic and Laissez-Faire Leadership Styles on the Success of the Organization: A Study on the Different Popular Restaurants of Mymensingh, Bangladesh," Can. J. Bus. 
Inf. Stud, vol. 1, no. 6, pp. 28-38, 2019.

[22] D. Supriyadi et al., "Innovation And Authentic Leadership Of Islamic University Lectures In Faculty Pharmacy Faculty: What Is The Role Of Psychological Capital," Syst. Rev. Pharm., vol. 11, no. 8, pp. 383-393, 2020.

[23] A. A. Al-Ali, S. K. Singh, M. Al-Nahyan, and A. S. Sohal, "Change management through leadership: the mediating role of organizational culture," Int. J. Organ. Anal., 2017.

[24] S. Sihombing, E. S. Astuti, M. Al Musadieq, D. Hamied, and K. Rahardjo, "The effect of servant leadership on rewards, organizational culture and its implication for employee's performance," Int. J. Law Manag., 2018.

[25] I. G. N. Arditha, P. Kepramreni, and I. N. Suardhika, "FACTORS AFFECTING OF ORGANIZATIONAL COMMITMENTS AND EFFECT TO EMPLOYEE PERFORMANCE," Int. J. Sustain. Educ. Glob. Creat. Econ., vol. 3, no. 1, pp. 411-421, 2020.

[26] G. Ben Saad and M. Abbas, "The impact of organizational culture on job performance: a study of Saudi Arabian public sector work culture," Probl. Perspect. Manag., vol. 16, no. 3, pp. 207-218, 2018.

[27] S. Pawirosumarto, P. K. Sarjana, and R. Gunawan, "The effect of work environment, leadership style, and organizational culture towards job satisfaction and its implication towards employee performance in Parador Hotels and Resorts, Indonesia," Int. J. Law Manag., 2017.

[28] G. Weerasinghe, "Organization culture impacts on employee motivation: A case study on an apparel company in Sri Lanka," 2017.

[29] A. Nikpour, "The impact of organizational culture on organizational performance: The mediating role of employee's organizational commitment," Int. J. Organ. Leadersh., vol. 6, pp. 65-72, 2017.

[30] R. van de Schoot et al., "An open source machine learning framework for efficient and transparent systematic reviews," Nat. Mach. Intell., vol. 3, no. 2, pp. 125-133, 2021.

[31] S. Szyller, B. G. Atli, S. Marchal, and N. Asokan, "Dawn: Dynamic adversarial watermarking of neural networks," in Proceedings of the 29th ACM International Conference on Multimedia, 2021, pp. 4417-4425.

[32] N. Susanti, V. W. Widajatun, M. B. Aji, and N. M. Nugraha, "IMPLICATIONS OF INTELLECTUAL CAPITAL FINANCIAL PERFORMANCE AND CORPORATE VALUES," Int. J. Psychosoc. Rehabil., vol. 24, no. 07, 2020. 